\title{
Antioxidant and antimicrobial alkaloids isolated from twigs of Uvaria grandiflora Roxb.
}

\author{
Naowarat Kongkum ${ }^{\mathrm{a}}$, Sariyarach Thanasansurapong ${ }^{\mathrm{b}}$, Nakin Surapanich ${ }^{\mathrm{c}}$, Wiyarat Kumutanat ${ }^{\mathrm{c}}$, \\ Chanchai Sukkum $^{\mathrm{d}}$, Chutima Kuhakarn ${ }^{\mathrm{b}}$, Thaworn Jaipetch ${ }^{\mathrm{b}}$, Vichai Reutrakul ${ }^{\mathrm{b}}$, \\ Sakchai Hongthong ${ }^{\mathrm{b}, \mathrm{c}, *}$ \\ ${ }^{a}$ Division of Chemistry, Faculty of Science and Technology, Surindra Rajabhat University, Surin 32000 \\ Thailand \\ b Department of Chemistry and Center Excellence for Innovation in Chemistry (PERCH-CIC), Faculty of \\ Science, Mahidol University, Bangkok 10400 Thailand \\ c Division of Chemistry, Faculty of Science and Technology, Rajabhat Rajanagarindra University, \\ Chachoengsao 24000 Thailand \\ d Division of Occupational Health and Safety, Faculty of Science and Technology, Rajabhat Rajanagarindra \\ University, Chachoengsao 24000 Thailand
}

*Corresponding author, e-mail: sakchai.hon@rru.ac.th

Received 11 Nov 2020

Accepted 19 Feb 2021

\begin{abstract}
Phytochemical investigation of the MeOH-EtOAc (1:1 v/v) soluble fraction partitioned from the MeOH extract of twigs of Uvaria grandiflora Roxb. led to the isolation of six known compounds including aristolactam AII (1), aristolactam BI (2), velutinam (3), griffithinam (4), isoursuline (5), and sinactine (6). Their structures were determined on the basis of spectroscopic analysis and comparison with the literature data. Described in this work is the first report of isoursuline (5), an azafluorene derivative, and sinactine (6), a tetrahydroepiberberine, being isolated from plants in the Uvaria genus. Antioxidant and antimicrobial activities of some isolated compounds were evaluated. Among screened compounds, velutinam (3) showed antioxidant activity in the DPPH radical scavenging assay.
\end{abstract}

KEYWORDS: Uvaria grandiflora, alkaloids, aristolactams, antioxidant activity, antimicrobial activity

\section{INTRODUCTION}

Uvaria genus belongs to the family Annonaceae. Plants in the Uvaria genus are distributed throughout tropical areas of Asia, Australia, and Africa, of which 15 species were reported to be found in various parts of Thailand [1]. Most of the Uvaria plants grown in Thailand are climbing shrubs and small trees. The fruits have deep orange, yellow, or rich red color, are usually aggregated, and are edible in some species [2]. Based on ethnopharmacological investigation, several species are used as folk medicine for treatment of several diseases. For example, the ethanolic extract of the roots of $U$. chamae was used as an antidiabetic agent and for the treatment of infections [3]. The decoction of the roots of $U$. cherrevensis was used for treatment of urinary disorders and being used as tonic for blood system and kidney [4].

Uvaria grandiflora Roxb. is a long climbing tree and is distributed in Southeast Asian countries including Vietnam, Malaysia, and Thailand. Various parts of $U$. grandiflora have long been used in traditional medicines for curing contusion and body tonic therapies and as a cardiotonic [5]. Previous phytochemical studies on the $U$. grandiflora resulted in the isolation of various types of compounds including polyoxygenated cyclohexene oxides [6], terpenoids [6], aromatic derivatives [7,8] as well as an alkaloid, velutinam [6], and some of which exhibited promising biological activities. For example, zeylenone, a polyoxygenated cyclohexenone derivative isolated from the leaves and roots of $U$. grandiflora, displayed significant cytotoxic activity in chronic myelogenous leukemia-derived K562 cell line in both in vitro and in vivo assays [9]. Inspired by the ethnomedicinal use of various parts of $U$. grandiflora as folk medicines and interesting biologically active components reported to be found in its leaves and roots, it is of high interest to further examine other plant parts of the $U$. grandiflora. In the course of our continuing efforts to search for biologically active substances from this plant [6-9], we reported herein the isolation and structural iden- 
tification of phytochemical components from the $\mathrm{MeOH}$ extract of twigs of $U$. grandiflora. It is worth mentioning that there was no prior phytochemical investigation on the twigs of $U$. grandiflora found in the literatures. Thus, the MeOH-EtOAc $(1: 1 \mathrm{v} / \mathrm{v})$ soluble fraction partitioned from the $\mathrm{MeOH}$ extract of twigs of $U$. grandiflora Roxb. was investigated and led to the isolation of six known compounds comprising aristolactam AII (1), aristolactam BI (2), velutinam (3), griffithinam (4), isoursuline (5), and sinactine (6). Antioxidant and antimicrobial activities of some isolated compounds were evaluated, and the results were described and discussed in this manuscript.

\section{MATERIALS AND METHODS}

\section{General experimental procedures}

${ }^{1} \mathrm{H},{ }^{13} \mathrm{C}$, and 2D NMR spectra were recorded on either a Bruker Ascend ${ }^{\mathrm{TM}} 400$ (Germany) spectrometer and/or a Jeol $400 \mathrm{YH}$ (Japan) spectrometer in deuterated chloroform $\left(\mathrm{CDCl}_{3}\right.$, Merck, Germany) or deuterated dimethyl sulfoxide (DMSO- $d_{6}$, Merck, Germany) solutions using TMS or residual nondeuterated solvent peak as an internal standard. Solvents for extraction, chromatography, and crystallization were distilled at their boiling point ranges prior to use. Pre-coated TLC aluminium sheets of silica gel $60 \mathrm{PF}_{254}(20 \times 20 \mathrm{~cm}$, layer thickness $0.2 \mathrm{~mm}$, Merck, Germany) were used for analytical purposes. The chemical compositions were visualized under ultraviolet light (at 254 and/or $365 \mathrm{~nm}$ ) and/or spraying with $12 \% \mathrm{H}_{2} \mathrm{SO}_{4}$ in ethanol, anisaldehyde solution, and/or Dragendoff's reagents. Plates of silica gel $\mathrm{PF}_{254}$ (5-40 $\mu \mathrm{m}$, Merck, Germany) were activated at $120^{\circ} \mathrm{C}$ for $2 \mathrm{~h}$ and utilized for preparative TLC separation. Column chromatography was performed by using silica gel 60 (60-200 $\mathrm{mm}$ or 70230 mesh ASTM, Merck, Germany) and Sephadex LH-20 (Merck, Germany).

\section{Plant materials}

The twigs of Uvaria grandiflora Roxb. were collected from Trang Province, Thailand in May 2019. The plant was identified by Dr. Sakchai Hongthong, and a voucher specimen (RRU-SH-008) was deposited at the Faculty of Science and Technology, Rajabhat Rajanagarindra University, Chachoengsao, Thailand.

\section{Extraction and isolation}

The air-dried and powdered twigs of $U$. grandiflora $(1.2 \mathrm{~kg})$ were extracted with EtOAc (3 $1 \times 5$ times) and $\mathrm{MeOH}(31 \times 5$ times) at room temperature.
After filtration and removal of the solvents under reduced pressure, the EtOAc extract (46.3 g) and $\mathrm{MeOH}$ extract $(154.8 \mathrm{~g}$ ) were obtained. The $\mathrm{MeOH}$ extract was dissolved in MeOH-EtOAc (1:1 v/v, $21)$ to provide $\mathrm{MeOH}-\mathrm{EtOAc}(1: 1 \mathrm{v} / \mathrm{v})$ soluble fraction $(92.0 \mathrm{~g})$ and insoluble residue $(49.1 \mathrm{~g})$ after removal of solvents under reduced pressure and freeze-drying. The MeOH-EtOAc (1:1 v/v) fraction was subjected to screening for its antioxidant activity using DPPH assay. Guided by the results of biological activity and the fraction with sufficient amount, the MeOH-EtOAc (1:1 v/v) fraction was first separated by vacuum column chromatography (VCC) technique using a gradient solvent system of EtOAc-hexanes (0-100\%) and MeOH-EtOAc $(0-100 \%)$ to give six subfractions (A1-A6).

Subfraction A2 (6.4 g) was purified using silica gel column chromatography (Si-gel CC) eluted with a gradient solvent system of EtOAc-hexanes (0-100\%) and MeOH-EtOAc (0-100\%) to afford subfractions A2.1-A2.4. Compound $6(66.9 \mathrm{mg})$ was obtained after A2.2 was purified on preparative thin layer chromatography (prep. TLC) using 5\% acetone-hexanes as eluent. Subfraction A2.3 was purified on Sephadex LH-20 CC (MeOH as eluent) and prep. TLC with 5\% EtOAc-hexanes as eluent to give compound 2 (17.1 mg).

After purification of A3 (7.3 g) on Si-gel CC with $\mathrm{MeOH}-\mathrm{CH}_{2} \mathrm{Cl}_{2}$ (0-100\%) as eluent, subfractions A3.1-A3.4 were obtained. Subfractions A3.2 and A3.3 were combined and purified on Sephadex LH20 CC eluted with $\mathrm{MeOH}$ followed by crystallization $\left(\mathrm{MeOH}-\mathrm{CH}_{2} \mathrm{Cl}_{2}\right)$ to provide compound $2(21.9 \mathrm{mg})$ and compound $3(64.0 \mathrm{mg})$.

Subfraction A4 (18.4 g) were fractionated by Si-gel CC using $\mathrm{MeOH}-\mathrm{CH}_{2} \mathrm{Cl}_{2}(0-100 \%)$ as eluent to afford subfractions A4.1-A4.7. Subfraction A4. 3 was chromatographed on Sephadex LH-20 CC eluted with $\mathrm{MeOH}$ to yield compound $1(18.2 \mathrm{mg}$ ). Subfraction A4.4 was isolated by Si-gel CC eluted with a gradient solvent system of $\mathrm{MeOH}-\mathrm{CH}_{2} \mathrm{Cl}_{2}$ (0-100\%) followed by Sephadex LH-20 column eluted with $\mathrm{MeOH}$ to give compound 5 (9.4 mg). Subfraction A4.5 was purified by Si-gel CC eluted with $\mathrm{MeOH}-\mathrm{CH}_{2} \mathrm{Cl}_{2}(0-100 \%)$ to give subfractions A4.5.1-A4.5.3. Purification of subfraction A4.5.1 on Sephadex LH-20 CC eluted with $\mathrm{MeOH}$ and prep. TLC using $5 \% \mathrm{MeOH}-\mathrm{CH}_{2} \mathrm{Cl}_{2}$ yielded compound 4 (25.0 mg) (for details of the ${ }^{1} \mathrm{H},{ }^{13} \mathrm{C}$ NMR and HRESI-MS data of each compound, see Tables S1-S3; and their ${ }^{1} \mathrm{H}$ and ${ }^{13} \mathrm{C}$ NMR spectra, see Figs. S1S12). 


\section{Antioxidant activity}

Antioxidant activity of fractions and isolated compounds was examined on the basis of the scavenging effect on the stable DPPH free radical activity. The samples were prepared in various concentrations by dissolution and dilution in $\mathrm{MeOH}$ (analytical grade). Two $\mathrm{ml}$ of methanol was added to $1 \mathrm{ml}$ of pure compound solution with different concentrations $(31.25,62.50,125,250$, and $500 \mu \mathrm{g} / \mathrm{ml})$ and the fraction solution $(93.75,187.50,375,750$, and $1500 \mu \mathrm{g} / \mathrm{ml}$ ). Four $\mathrm{ml}$ of methanolic solution of $0.3 \mathrm{mM}$ DPPH was added, and the mixture was shaken vigorously. The mixtures were immediately incubated at room temperature in the absence of light for $30 \mathrm{~min}$ before the absorbance at $517 \mathrm{~nm}$ was measured. The assay was performed in triplicate. The percentage of inhibition of DPPH free radical was evaluated following the below equation.

$$
\text { (\%) inhibition }=\frac{\mathrm{AB}-\mathrm{AA}}{\mathrm{AB}} \times 100
$$

where $\mathrm{AA}$ and $\mathrm{AB}$ are the absorbance values of the test and of the blank sample, respectively. $\mathrm{IC}_{50}$ value indicating the concentration at which a sample would inhibit free radicals by $50 \%$ was also calculated [10].

\section{Antimicrobial activity}

The antibacterial activity against Gram-positive bacteria: Staphylococcus aureus (ATCC29213), Gramnegative bacteria: Escherichia coli (ATCC25922), and fungal pathogen: Candida albicans (ATCC 10231) was examined by disc diffusion method and was performed at Scientific Instruments Centre, Faculty of Science, King Mongkut's Institute of Technology Ladkrabang, Bangkok, Thailand. Maximum tested concentration was done at $10 \mu \mathrm{g} / \mathrm{ml}$ for antibacterial activity. The disc diffusion test was performed. The inoculum suspension of each microbial strain was swabbed on the entire surface of Mueller-Hinton agar (MHA, Difco) for bacteria and SDA for yeasts. Sterile $6 \mathrm{~mm}$ filter paper discs were aseptically placed on MHA and SDA surfaces. Twenty $\mu$ l of sample was immediately added to discs. A $20 \mu \mathrm{l}$ aliquot of $10 \%$ DMSO was also added to a sterile paper disc as a negative control. Penicillin $\mathrm{G}(10 \mathrm{unit} / \mathrm{ml})$, gentamicin $(10 \mu \mathrm{g} / \mathrm{ml})$, and nystatin $(10 \mu \mathrm{g} / \mathrm{ml})$ were used as positive controls for $S$. aureus, E. coli, and C. albicans test, respectively. The plates were left at ambient temperature for 15 min to allow excess prediffusion of extracts prior to incubation at $37^{\circ} \mathrm{C}$ for $24 \mathrm{~h}$ for bacteria and at $30^{\circ} \mathrm{C}$ for $72 \mathrm{~h}$ for fungus. Diameters of inhibition zones were measured [11].

\section{RESULTS AND DISCUSSION}

Chromatographic purification of the MeOH-EtOAc $(1: 1 \mathrm{v} / \mathrm{v})$ soluble fraction partitioned from the $\mathrm{MeOH}$ extract of twigs of $U$. grandiflora Roxb. yielded the known compounds 1-6. By comparison of their spectroscopic data with those previously reported in the literature, the structures of the isolated compounds were identified as four aristolactam derivatives: aristolactam AII (1) [12], aristolactam BI (2) [12], velutinam (3) [12], and griffithinam (4) [13]; an azafluorene, isoursuline (5) [14], and a tetrahydroepiberberine, sinactine (6) [15]; see Fig. 1. The spectroscopic data including ${ }^{1} \mathrm{H},{ }^{13} \mathrm{C}$ NMR, and HR-ESI-MS data were summarized and mentioned in Supplementary data, Tables S1-S3, respectively.

To date, many plant species of the Uvaria genus have been thoroughly investigated, and a number of biologically active substances were characterized and reported. Among those, polyoxygenated cyclohexene derivatives are a large group found in the plants of the Uvaria genus. Zeylenone, a natural cyclohexene oxide first isolated from the EtOH extract of the leaves of $U$. grandiflora, exhibited strong suppressive activity in several cancer cells [9]. Aristolactams were reported as a common type of alkaloids found in the Uvaria genus. Piperolactam C was isolated as a major component from the $\mathrm{MeOH}$ extract of stem bark of $U$. hamiltonii [16] together with aristolactam AIII, aristolactam BII, goniopedaline, and griffithinam [17]. A few aporphine alkaloids consisting of crotspatine, crotonosine, and zenkerine were isolated from the stems of U. klaineana [18]. In addition, indole derivatives, 3-farnesylindole, and its derivatives were isolated from the $\mathrm{MeOH}$ extract of the root bark of $U$. pandensis [19]. Recent study of $U$. grandiflora revealed that an aristolactam, velutinam (3), was isolated from the aerial parts of $U$. grandiflora [20]. The present work expanded the library of aristolactam alkaloids including aristolactam AII (1) [12], aristolactam BI (2) [12], and griffithinam (4) [13] to be isolated from U. grandiflora. Additionally, an azafluorene, isoursuline (5) [14], and a tetrahydroepiberberine, sinactine (6) [15], were isolated for the first time from plants in the Uvaria genus. Moreover, velutinam (3) and griffithinam (4) were considered potential chemotaxonomic markers for plants in the Uvaria genus. On the basis of an extensive review on alkaloids derived from plants in the Uvaria 


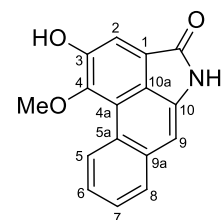

(1)

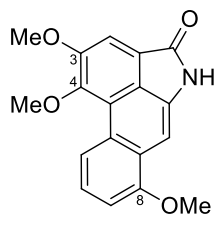

(2)

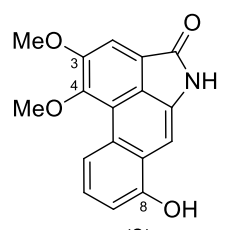

(3)

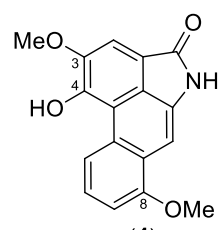

(4)

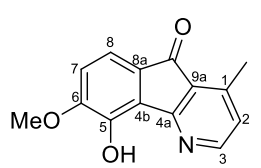

(5)

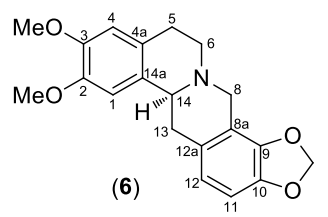

Fig. 1 Structure of compounds 1-6.

genus along with our present research results, the aristolactam derivatives can be considered powerful evidences to support the taxonomic location of the Uvaria plants. The MeOH-EtOAc (1:1 v/v) soluble fraction and the isolated compounds $1-4$ and 6 were evaluated for their antioxidant activity using DPPH free radical scavenging assay. The $\mathrm{MeOH}-\mathrm{EtOAc}(1: 1 \mathrm{v} / \mathrm{v})$ soluble fraction and velutinam (3) exhibited free radical scavenging activity with an $\mathrm{IC}_{50}(50 \%$ inhibitory concentration) values of $310.0 \pm 7.6$ and $240.1 \pm 6.5 \mu \mathrm{g} / \mathrm{ml}$, respectively. Compounds $1-2$, 4 , and 6 were inactive in the DPPH free radical scavenging assay (Table 1 ). The antimicrobial activity against tested microbes including Staphylococcus aureus (ATCC29213), Escherichia coli (ATCC25922), and Candida albicans (ATCC 10231) at $10 \mu \mathrm{g} / \mathrm{ml}$ concentration revealed that all the compounds screened did not show inhibitory activity (for information detail; see Table S4). According to literature reports, the crude extracts and pure compounds isolated from various parts of $U$. grandiflora were examined for several biological activities such as cytotoxic, anti-inflammatory, antioxidant, and antimicrobial activities [6-9,20-22]. To the best our search from SciFinder database, compounds 16 have never been investigated for their antioxidant activity. Therefore, described in this work was the first study on antioxidant activity of compounds 1-4 and 6. Aristolactam AII (1) and velutinam (3) isolated from Goniothalamus velutinus were previously examined for their antimicrobial activity against Bacillus subtilis, Bacillus spizizenii, and Staphylococcus aureus and found to be inactive [23]. In the present work, velutinam (3) isolated from U. grandiflora also did not exhibit antimicrobial activity to all tested bacterial strains. Thus, our observation on antimicrobial activity of velutinam (3) agreed well with the previous report [23].
Table 1 Antioxidant activity of MeOH-EtOAc (1:1 v/v) soluble fraction, isolated compounds $1-4$, and 6 isolated from the twigs of $U$. grandiflora on DPPH free radical.

\begin{tabular}{ll}
\hline Sample & $\mathrm{IC}_{50}(\mu \mathrm{g} / \mathrm{ml})$ \\
\hline MeOH-EtOAc (1:1 v/v) fraction & $310.0 \pm 7.6$ \\
Aristolactam AII (1) & Inactive \\
Aristolactam BI (2) & Inactive \\
Velutinam (3) & $240.1 \pm 6.5$ \\
Griffithinam (4) & Inactive \\
Sinactine (6) & Inactive \\
Quercetin & $40.9 \pm 0.8$ \\
\hline
\end{tabular}

Results are average of three independent experiments \pm standard deviation. Quercetin was used as a positive control. Inactive $=>500 \mu \mathrm{g} / \mathrm{ml}$.

\section{CONCLUSION}

The present study described phytochemical investigation on the $\mathrm{MeOH}-\mathrm{EtOAc}(1: 1 \mathrm{v} / \mathrm{v})$ soluble fraction partitioned from the $\mathrm{MeOH}$ extract of twigs of $U$. grandiflora Roxb. and led to the isolation of four aristolactams 1-4, azafluorene 5, and tetrahydroepiberberine 6. Except for velutinam (3), aristolactam AII (1), aristolactam BI (2), and griffithinam (4) were isolated for the first time from $U$. grandiflora. It is also worth emphasizing that isoursuline (5) and sinectine (6) were isolated for the first time from the Uvaria genus. In addition, velutinam (3) and griffithinam (4) are potentially being used as chemotaxonomic markers for plants in the Uvaria genus. For biological activity aspects, except for compound 5, there was no prior report on antioxidant activity of other isolated compounds examined in this work. Among compounds screened for their antioxidant and antimicrobial activities, only velutinam (3) exhibited antioxidant activity in the DPPH radical scavenging assay. 


\section{Appendix A. Supplementary data}

Supplementary data associated with this article can be found at http://dx.doi.org/10.2306/ scienceasia1513-1874.2021.S002.

Acknowledgements: NK acknowledged Faculty of Science and Technology, Surindra Rajabhat University. NS, WK, CS, and SH acknowledged Faculty of Science and Technology, Rajabhat Rajanagarindra University. We also thank Center of Excellence for Innovation in Chemistry (PERCH-CIC), the Office of the Higher Education Commission, Ministry of Higher Education, Science, Research and Innovation, Thailand and Mahidol University for laboratory equipment and spectroscopic measurements.

\section{REFERENCES}

1. Meade CV, Parnell JAN (2018) A revised taxonomy for Uvaria (Annonaceae) in continental Asia. Aust Syst Bot 31, 311-356.

2. Suthiphasilp V, Maneerat W, Andersen RJ, Patrick BO, Phukhatmuen P, Pyne SG, Laphookhieo S (2019) Uvarialuridols A-C, three new polyoxygenated cyclohexenes from the twig and leaf extracts of Uvaria lurida. Fitoterapia 138, ID 104340.

3. Koudokpon H, Armstrong N, Dougnon TV, Fah L, Hounsa E, Bankolé HS, Loko F, Chabrière E, et al (2018) Antibacterial activity of chalcone and dihydrochalcone compounds from Uvaria chamae roots against multidrug-resistant bacteria. BioMed Res Int 2018, ID 1453173.

4. Jaipetch T, Hongthong S, Kuhakarn C, Pailee P, Piyachaturawat P, Suksen K, Kongsaeree K, Prabpai S, et al (2019) Cytotoxic polyoxygenated cyclohexene derivatives from the aerial parts of Uvaria cherrevensis. Fitoterapia 137, ID 104182.

5. Chuakul W, Sornthornchareonon N (2003) Ethnomedical uses of Thai Annonaceous plants. Thai $J$ Phytopharm 10, 25-32.

6. Ho DV, Kodama T, Le HTB, Phan KV, Do TT, Bui TH, Le AT, Win NN, et al (2015) A new polyoxygenated cyclohexene and a new megastigmane glycoside from Uvaria grandiflora. Bioorg Med Chem Lett 25, 3246-3250.

7. Ankisetty S, ElSohly HN, Li XC, Khan SI, Tekwani BL, Smillie T, Walker L (2006) Aromatic constituents of Uvaria grandiflora. J Nat Prod 69, 692-694.

8. Macabeo APG, Flores AIG, Fernandez RAT, Budde S, Faderl C, Dahse HM, Franzblau SG (2020) Antitubercular and cytotoxic polyoxygenated cyclohexane derivatives from Uvaria grandiflora. Nat Prod Res $1-4$.

9. Huo X, Liao Y, Tian Y, Gao L, Cao L (2016) Zeylenone promotes apoptosis in chronic myelogenous leukemia-derived K562 cells by a mechanism involving Jak2 and Src kinase. RSC Adv 6, 114096-114108.
10. Veeru P, Kishor MP (2009) Screening of medicinal plant extracts for antioxidant activity. $J$ Med Plants Res 3, 608-612.

11. Supong K, Thawai C, Supothina S, Auncharoen P, Pittayakhajonwut P (2016) Antimicrobial and antioxidant activities of quinoline alkaloids from Pseudomonas aeruginosa BCC76810. Phytochem Lett 17, 100-106.

12. Yang XN, Jin YS, Zhu P, Chen HS (2010) Amides from Uvaria microcarpa. Chem Nat Compd 46, 324-326.

13. Zhang YJ, Kong M, Chen RY, Yu DQ (1999) Alkaloids from the roots of Goniothalamus griffithii. J Nat Prod 62, 1050-1052.

14. Mueller D, Davis RA, Duffy S, Avery VM, Camp D, Quinn RJ (2009) Antimalarial activity of azafluorenone alkaloids from the Australian tree Mitrephora diversifolia. J Nat Prod 72, 1538-1540.

15. Seger C, Sturm S, Stasser EM, Ellmerrer E, Stuppner $\mathrm{H}(2004){ }^{1} \mathrm{H}$ and ${ }^{13} \mathrm{C}$ NMR signal assignment of benzylisoquinoline alkaloids from Fumaria officinalis L. (Papaveraceae). Magn Reson Chem 42, 882-886.

16. Hasan CM, Asha KN, Rashid MA (2001) Aristolactams from the stem bark of Uvaria hamiltonii. Biochem Syst Ecol 29, 207-208.

17. Asha KN, Chowdhury R, Hassan CM, Rashid MA (2003) Antibacterial activity and cytotoxicity of extractives from Uvaria hamiltonii stem bark. Fitoterapia 74, 159-163.

18. Akendengue B, Ngou-Milama E, Roblot F, Laurens A, Hocquemiller R, Grellier PH, Frappier F (2002) Antiplasmodial activity of Uvaria klaineana. Planta Med 68, 167-169.

19. Nkunya MHH, Weenen H (1989) Two indolosesquiterpenes from Uvaria pandensis. Phytochemistry 8, 2217-2218.

20. VietHo D, Kodama T, Le HTB, Phan KV, Do TT, Buic $\mathrm{TH}$, Le AT, Win NN, et al (2015) A new polyoxygenated cyclohexene and a new megastigmane glycoside from Uvaria grandiflora. Bioorg Med Chem Lett 16, 3246-3250.

21. Seangphakdee P, Pompimon W, Meepowpan P, Panthong A, Chiranthanut N, Banjerdpongchai R, Wudtiwai B, Nuntasaen N, et al (2013). Anti-inflammatory and anticancer activities of (-)-zeylenol from stems of Uvaria grandiflora. ScienceAsia 39, 610-614.

22. Syafiqah NAN, Shahadat HM, Teng JK, Veeranoot N, Chairat U, Parichat P, Mohammed R, Tooba M, et al (2018) Anti-infective activities of 11 plants species used in traditional medicine in Malaysia. Exp Parasitol 194, 67-78.

23. Iqbal E, Lim LBL, Salim KA, Faizi S, Ahmed A, Mohamed AJ (2018) Isolation and characterization of aristolactam alkaloids from the stem bark of Goniothalamus velutinus (Airy Shaw) and their biological activities. J King Saud Univ Sci 30, 41-48. 


\section{Appendix A. Supplementary data}

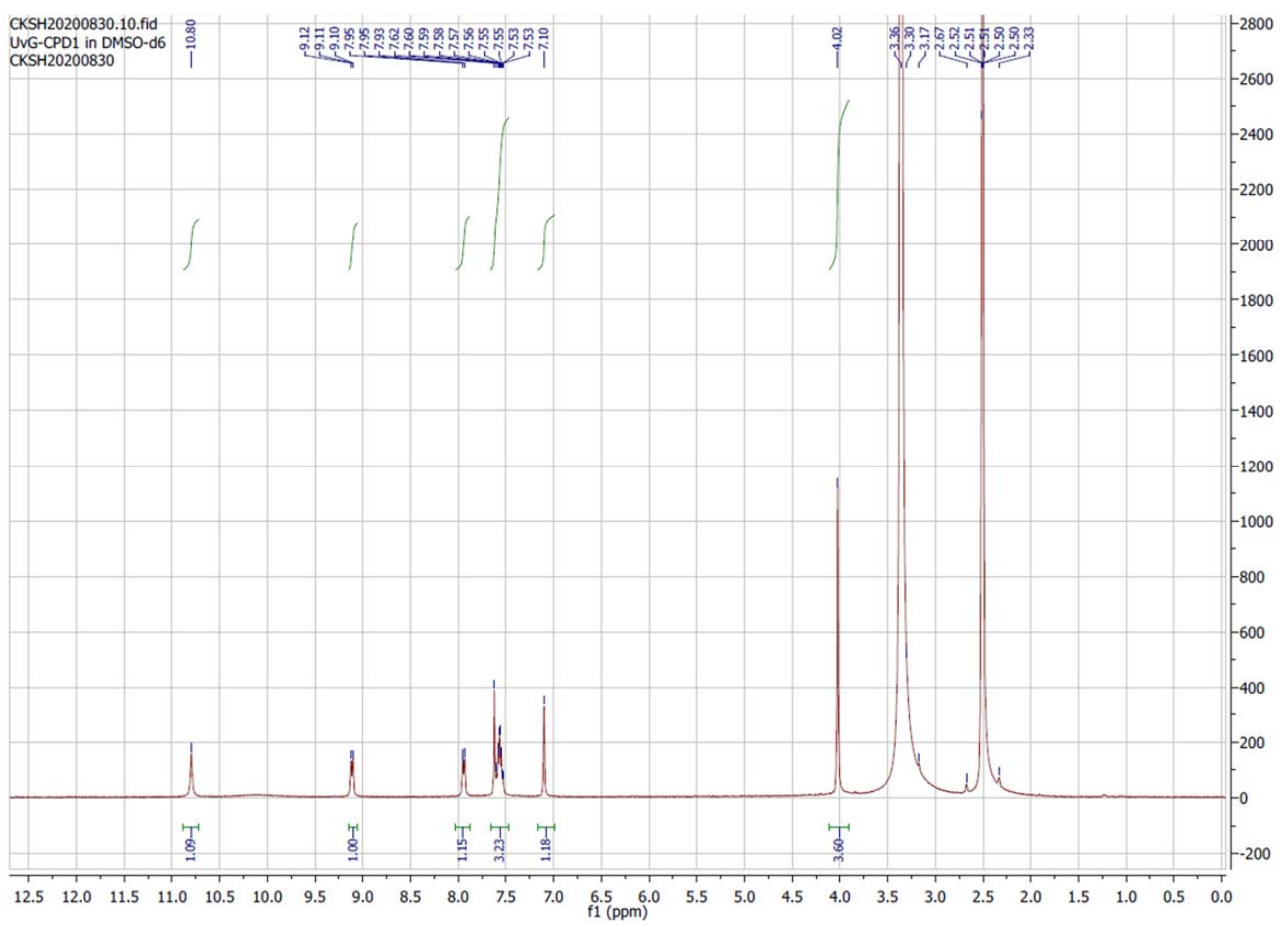

Fig. S1 The ${ }^{1} \mathrm{H}$ NMR spectrum of aristolactam AII (1) in DMSO- $d_{6}$.

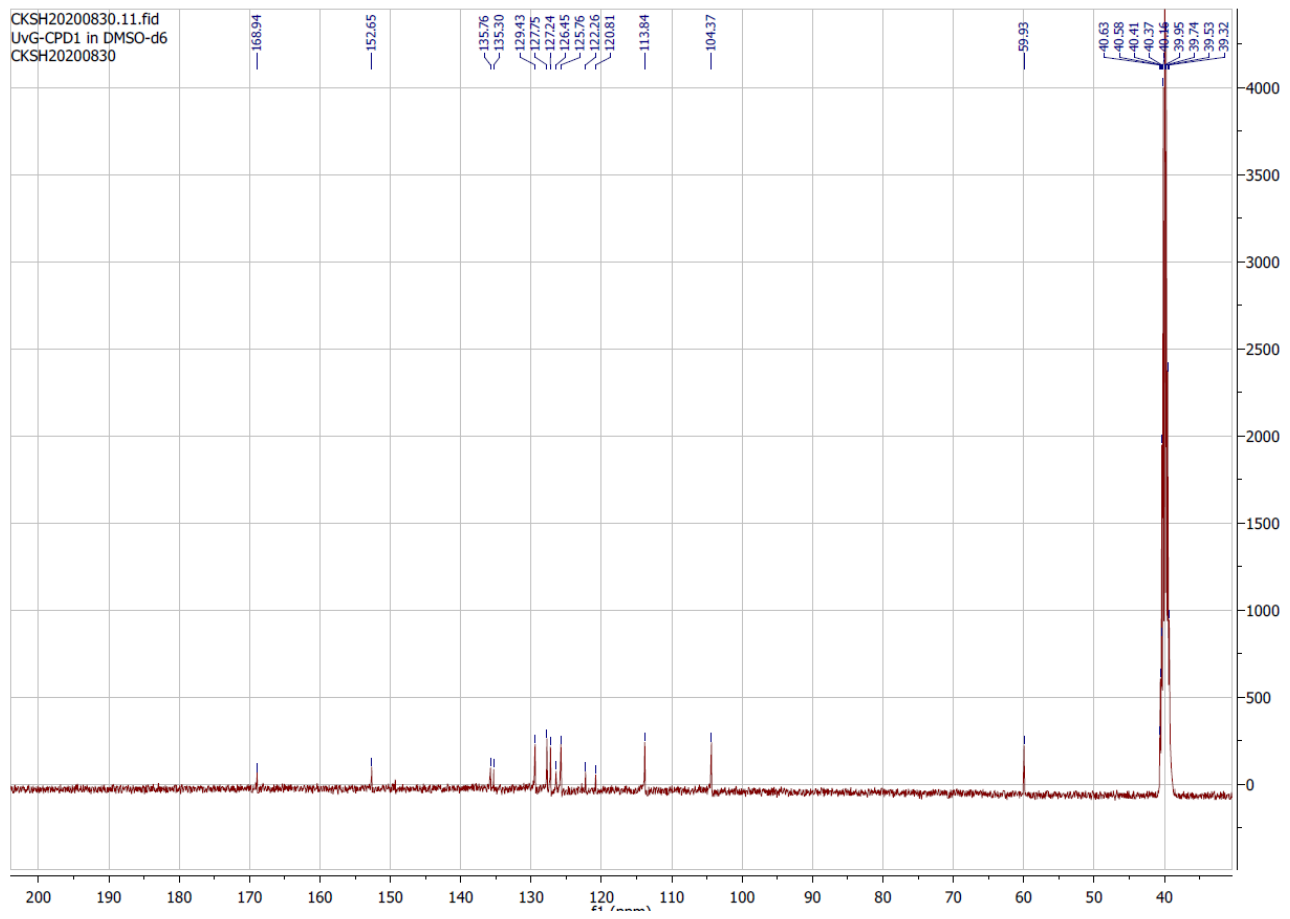

Fig. S2 The ${ }^{13} \mathrm{C}$ NMR spectrum of aristolactam AII (1) in DMSO- $d_{6}$. 


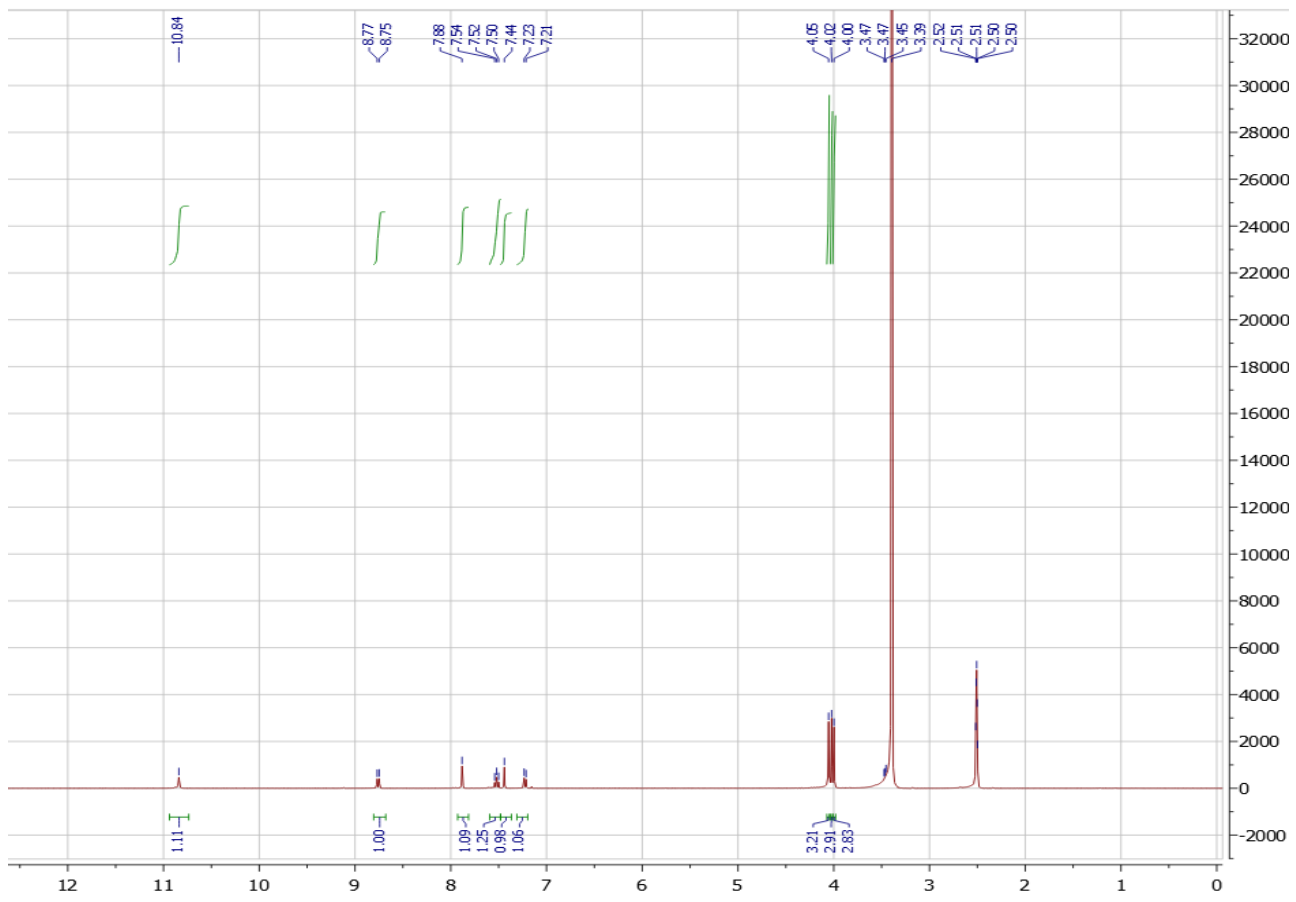

Fig. S3 The ${ }^{1} \mathrm{H}$ NMR spectrum of aristolactam BI (2) in DMSO- $d_{6}$.

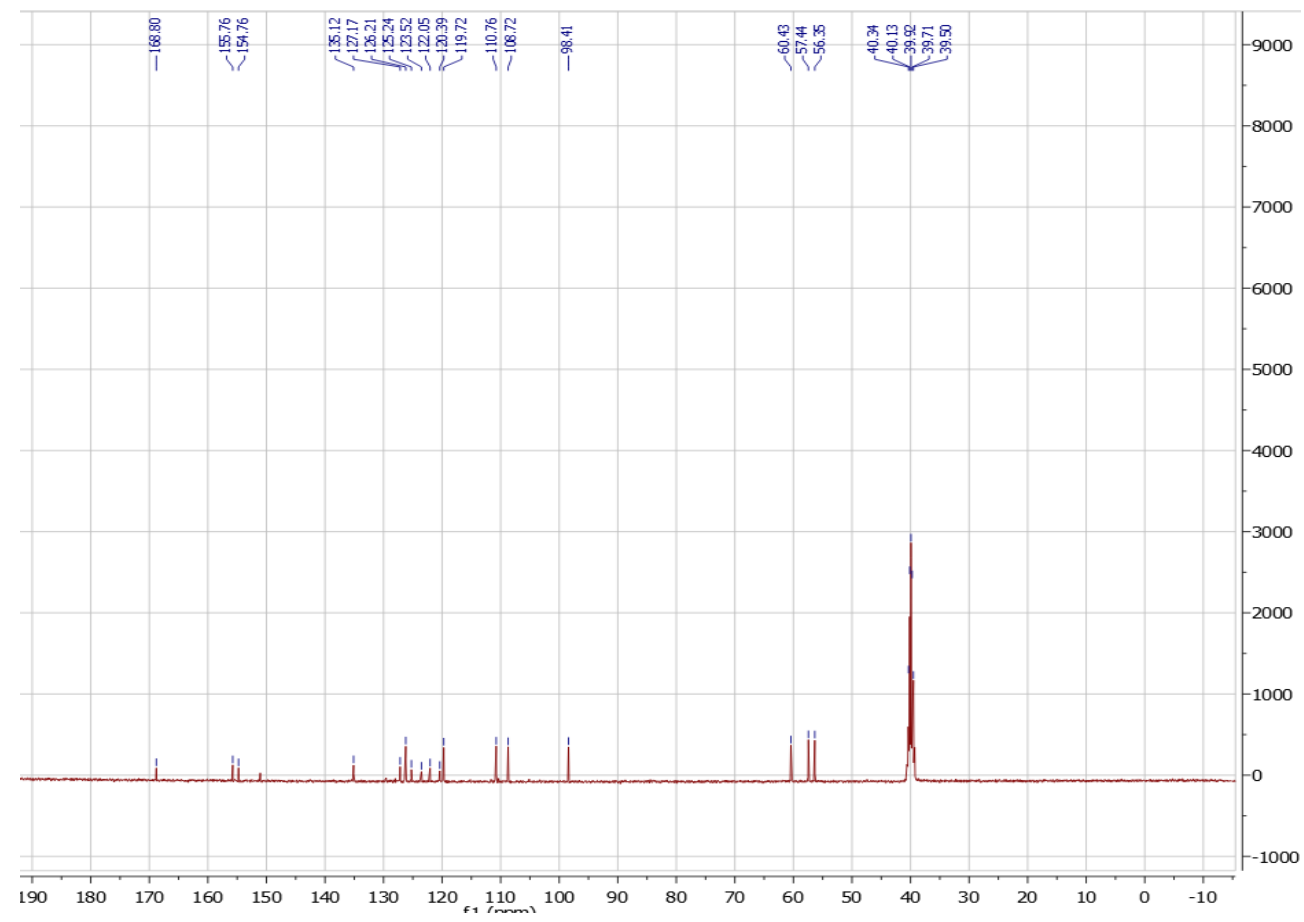

Fig. S4 The ${ }^{13} \mathrm{C}$ NMR spectrum of aristolactam BI (2) in DMSO- $d_{6}$. 


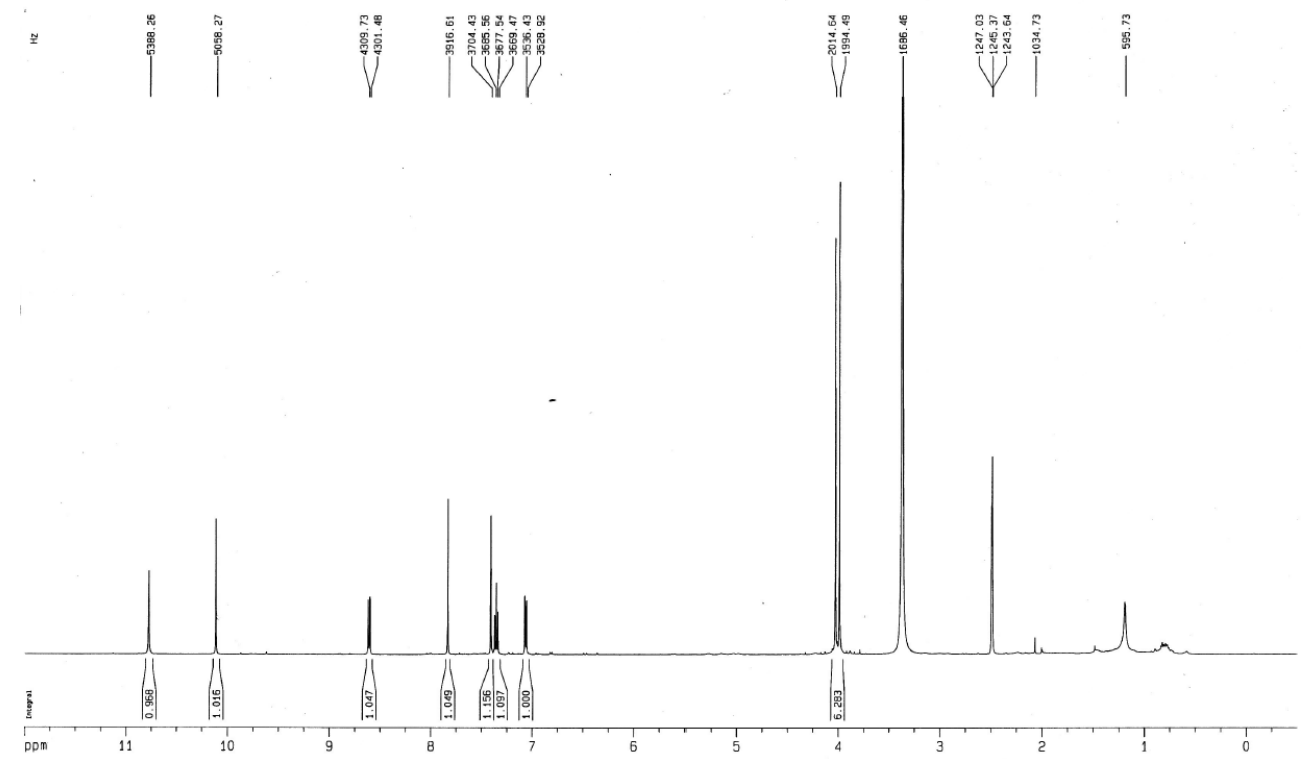

Fig. S5 The ${ }^{1} \mathrm{H}$ NMR spectrum of velutinam (3) in DMSO- $d_{6}$.

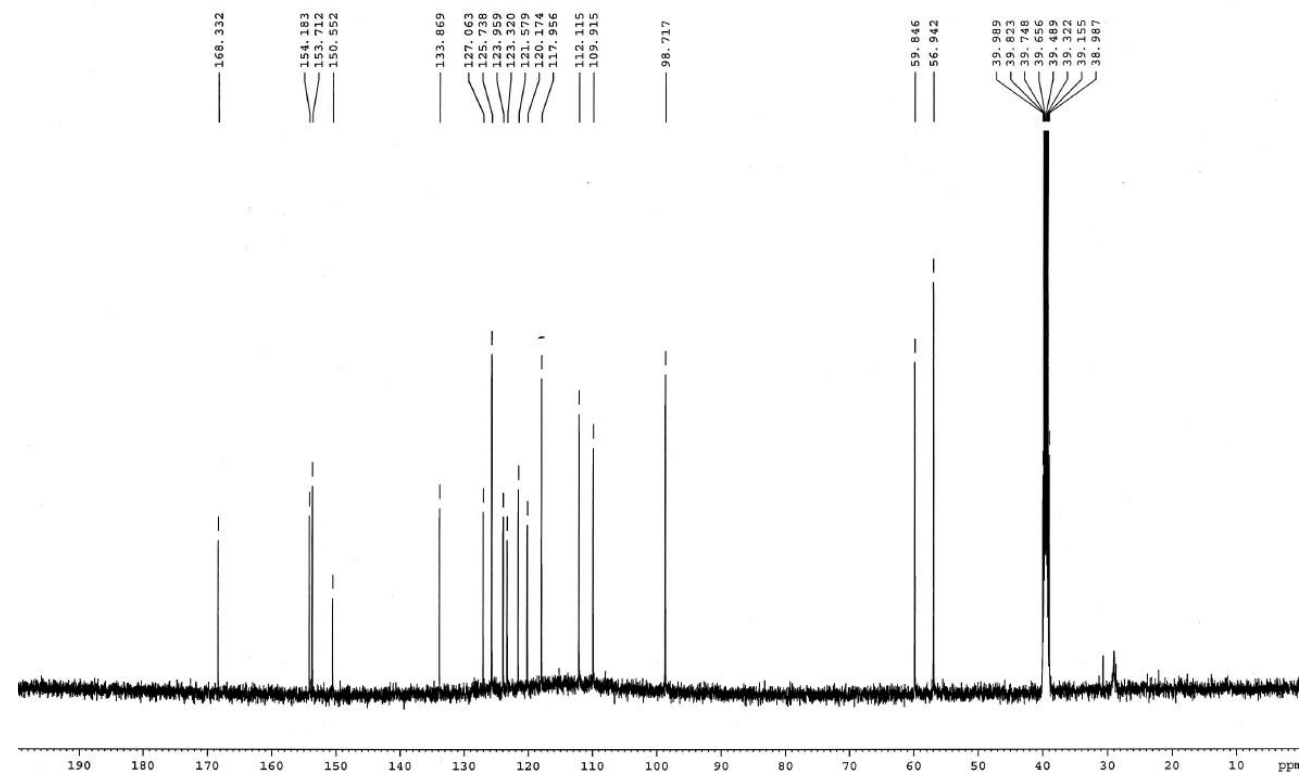

Fig. S6 The ${ }^{13} \mathrm{C}$ NMR spectrum of velutinam (3) in DMSO- $d_{6}$. 


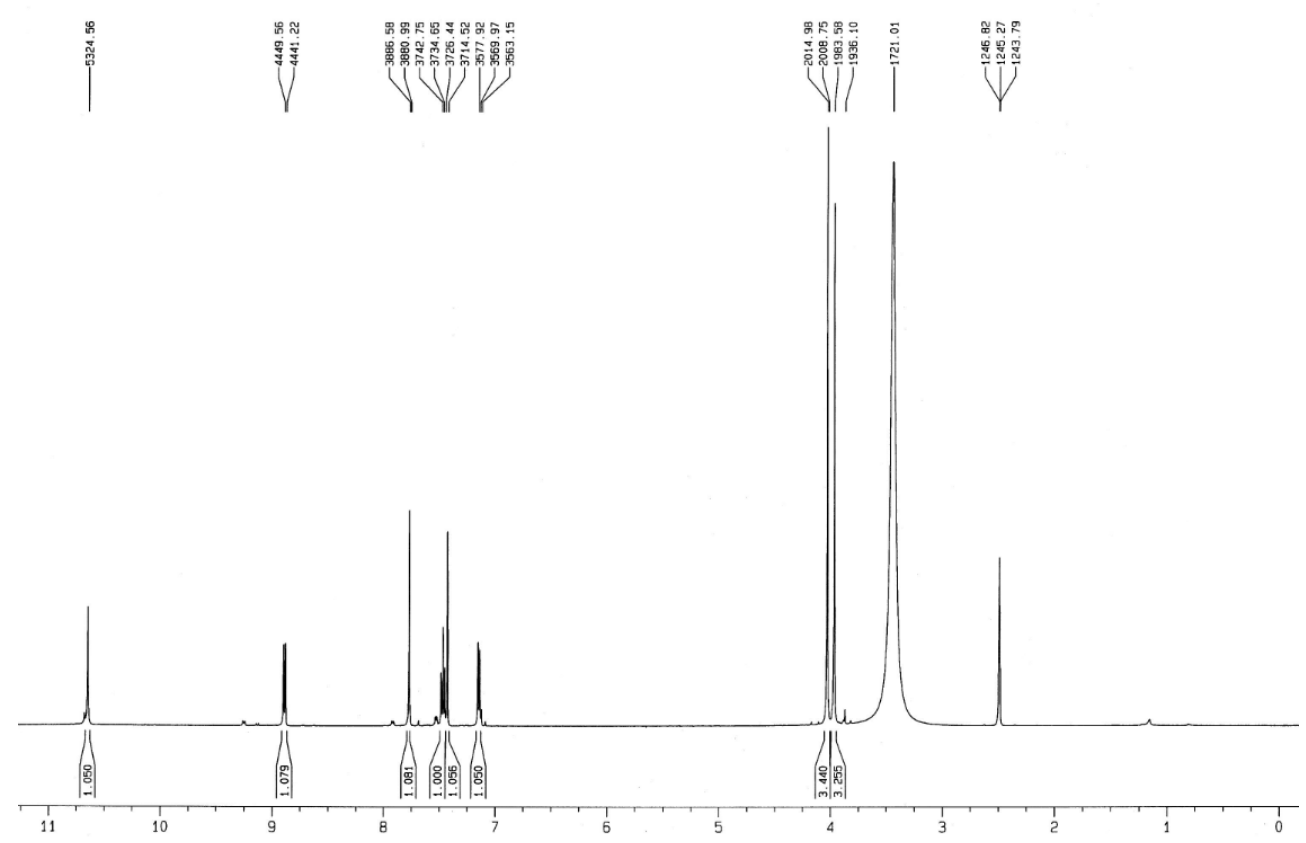

Fig. S7 The ${ }^{1} \mathrm{H}$ NMR spectrum of griffithinam (4) in DMSO- $d_{6}$.
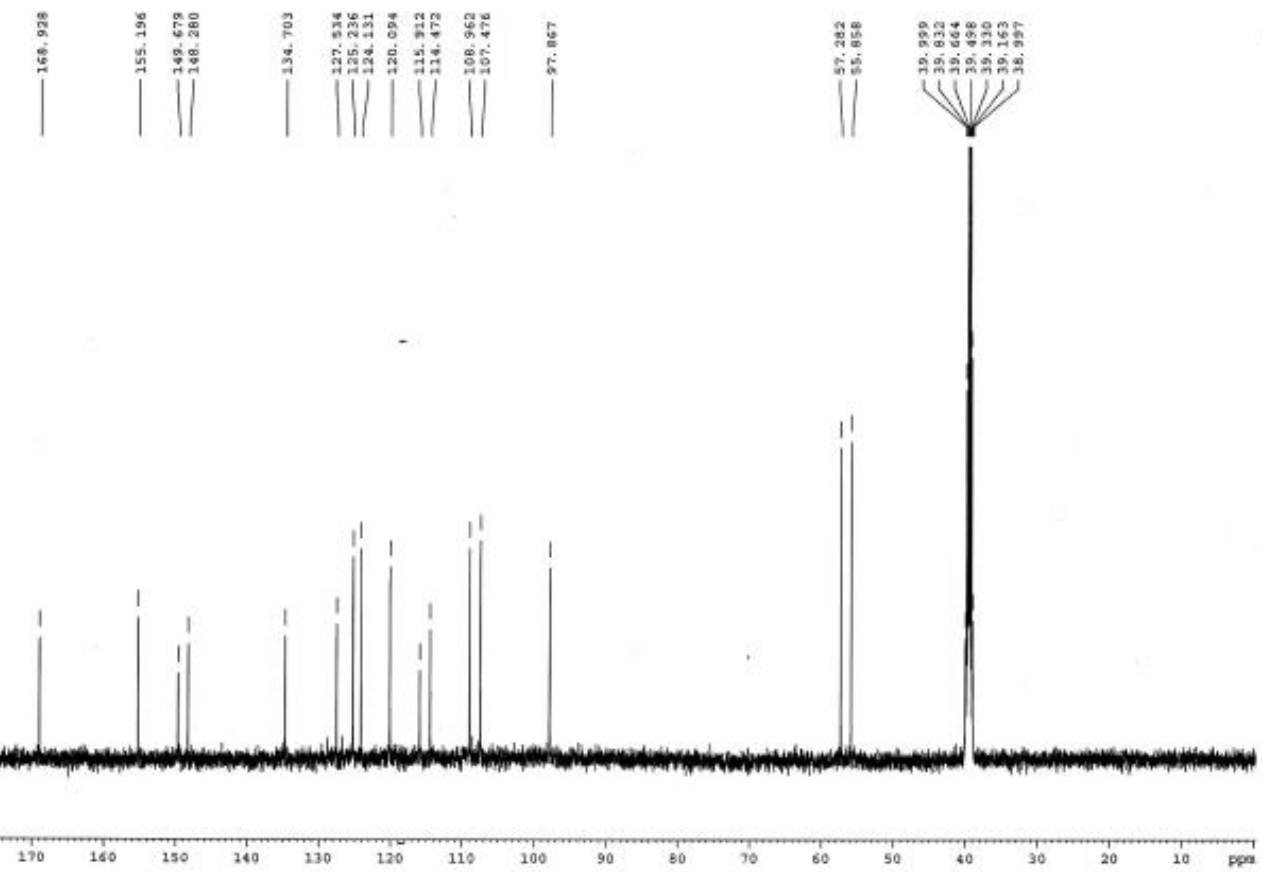

Fig. S8 The ${ }^{13} \mathrm{C}$ NMR spectrum of griffithinam (4) in DMSO- $d_{6}$. 


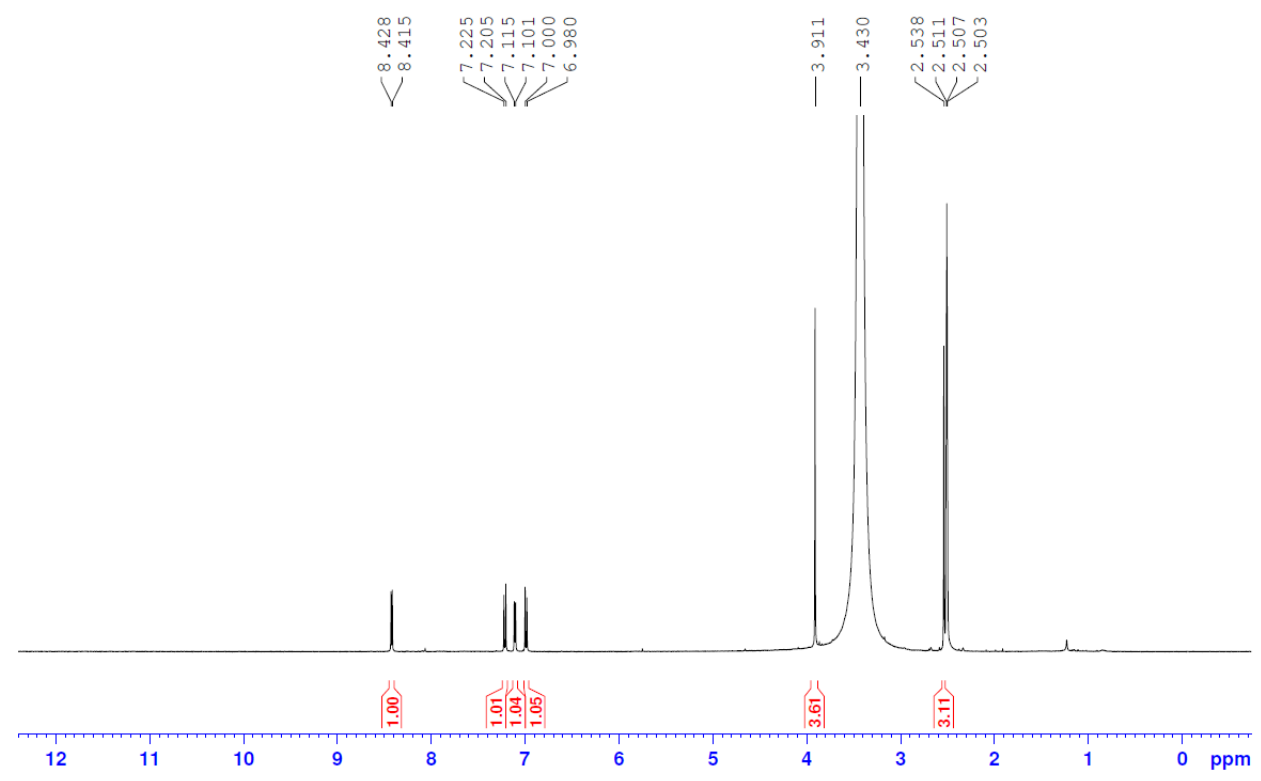

Fig. S9 The ${ }^{1} \mathrm{H}$ NMR spectrum of isoursuline (5) in DMSO- $d_{6}$.

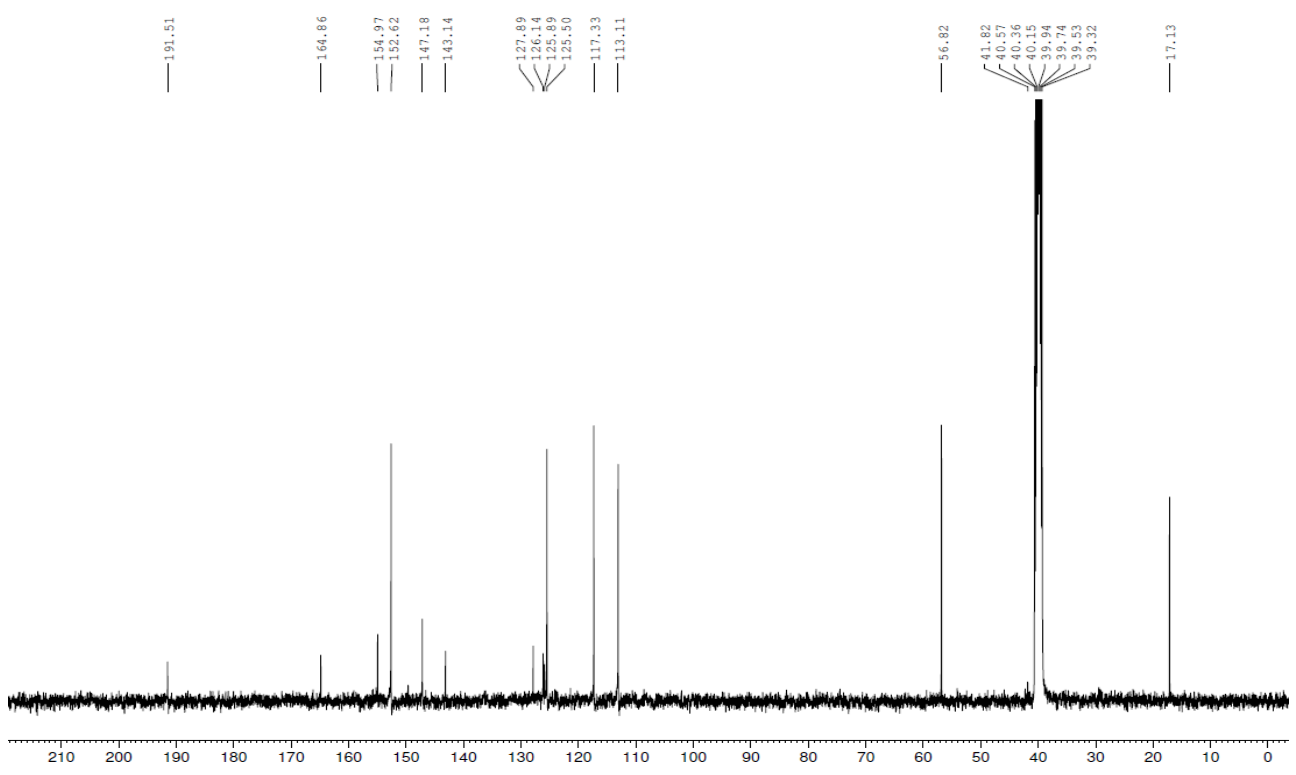

Fig. S10 The ${ }^{13} \mathrm{C}$ NMR spectrum of isoursuline (5) in DMSO- $d_{6}$. 


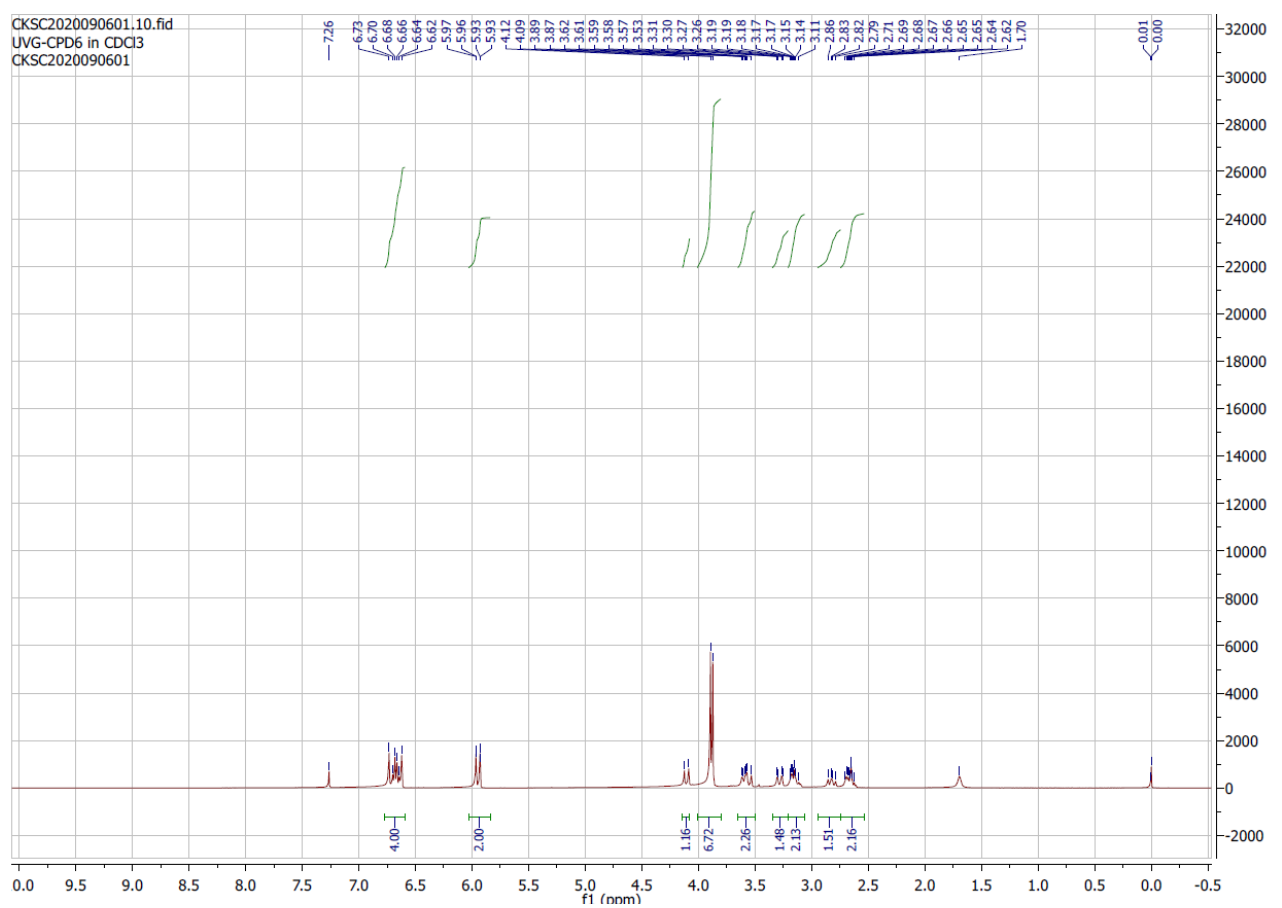

Fig. S11 The ${ }^{1} \mathrm{H}$ NMR spectrum of sinactine (6) in $\mathrm{CDCl}_{3}$.

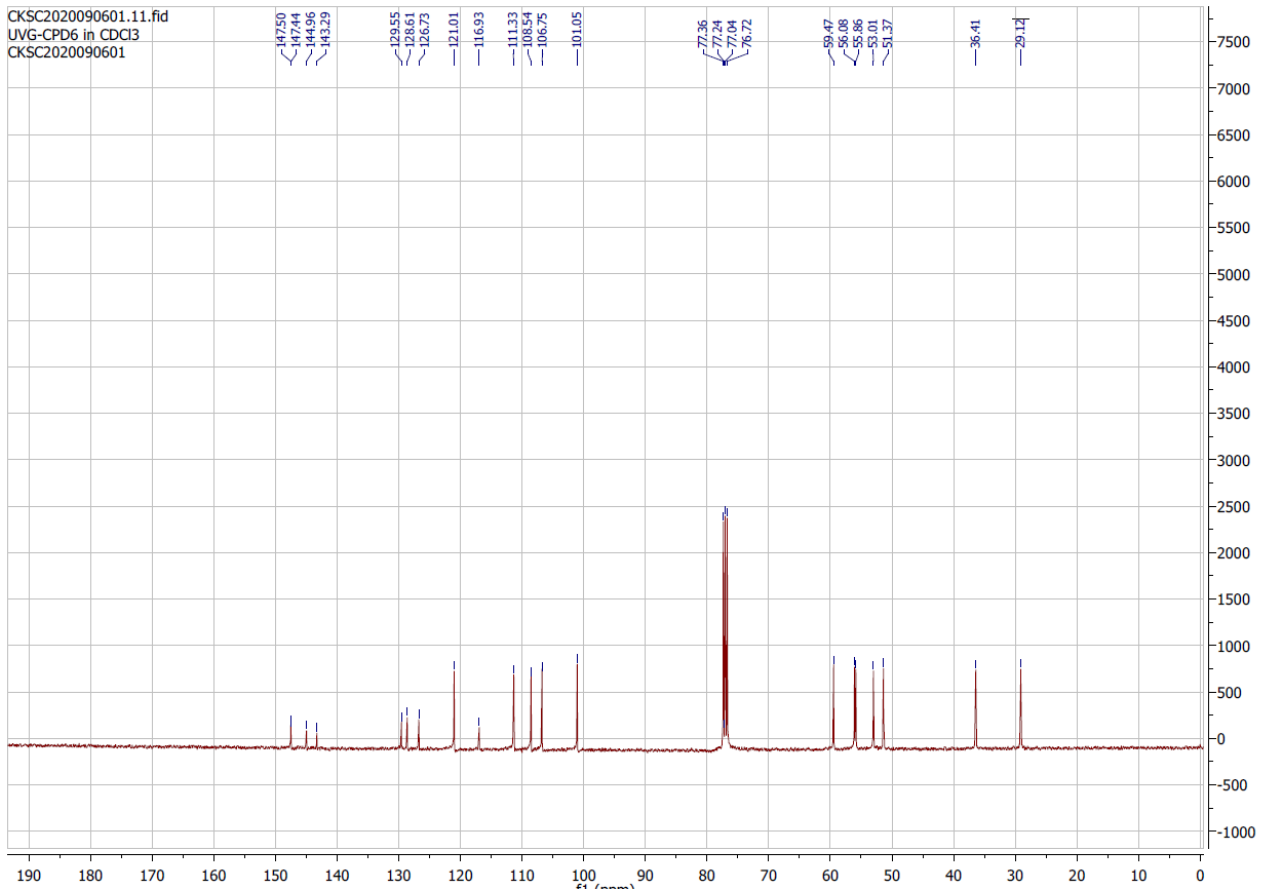

Fig. S12 The ${ }^{13} \mathrm{C}$ NMR spectrum of sinactine (6) in $\mathrm{CDCl}_{3}$. 
Table S1 ${ }^{1} \mathrm{H}$ NMR data of compounds 1-6.

\begin{tabular}{|c|c|c|c|c|c|c|}
\hline position & $\begin{array}{l}1 \text { in DMSO- } d_{6} \delta_{H}, \\
\text { mult, } J(\mathrm{~Hz})^{\mathrm{a}}\end{array}$ & $\begin{array}{l}2 \text { in DMSO- } d_{6} \delta_{H}, \\
\text { mult, } J(\mathrm{~Hz})^{\mathrm{a}}\end{array}$ & $\begin{array}{l}3 \text { in DMSO- } d_{6} \delta_{H}, \\
\text { mult, } J(\mathrm{~Hz})^{\mathrm{b}}\end{array}$ & $\begin{array}{l}4 \text { in DMSO- } d_{6} \delta_{H}, \\
\text { mult, } J(\mathrm{~Hz})^{\mathrm{b}}\end{array}$ & $\begin{array}{l}5 \text { in DMSO- } d_{6} \delta_{H}, \\
\text { mult, } J(H z)^{\mathrm{a}}\end{array}$ & $\begin{array}{l}6 \text { in } \mathrm{CDCl}_{3} \delta_{H}, \\
\text { mult, } J(\mathrm{~Hz})^{\mathrm{a}}\end{array}$ \\
\hline 1 & - & - & - & - & - & $6.73-6.62, \mathrm{~m}$ \\
\hline 2 & $7.62, \mathrm{~s}$ & $7.88, \mathrm{~s}$ & $7.83, \mathrm{~s}$ & $7.61, \mathrm{~s}$ & $7.11, \mathrm{~d}(5.3)$ & - \\
\hline 3 & - & - & - & - & $8.42, \mathrm{~d}(5.3)$ & - \\
\hline 4 & - & - & - & - & - & $6.73-6.62, \mathrm{~m}$ \\
\hline 5 & $9.11, \mathrm{~d}(8.1)$ & $8.76, \mathrm{~d}(8.3)$ & $8.61, \mathrm{~d}(8.0)$ & $8.89, \mathrm{~d},(8.3)$ & - & $\begin{array}{l}\text { a) } 3.25-3.11, \mathrm{~m} \\
\text { b) } 2.77-2.61, \mathrm{~m}\end{array}$ \\
\hline 6 & $7.60-7.53, \mathrm{~m}$ & $7.52, \mathrm{t}(8.2)$ & $7.35, \mathrm{t}(8.0)$ & $7.46, \mathrm{~d},(8.2)$ & - & $\begin{array}{l}\text { a) } 3.28 \text {, dd }(15.9,3.7 \\
\text { b) } 2.77-2.61, \mathrm{~m}\end{array}$ \\
\hline 7 & $7.60-7.53, \mathrm{~m}$ & $7.22, \mathrm{~d}(8.0)$ & $7.06, \mathrm{~d}(8.0)$ & $7.14, \mathrm{~d},(8.0)$ & $6.99, \mathrm{~d}(8.0)$ & D) $2.11-2.01,111$ \\
\hline 8 & $7.94, \mathrm{~d}(8.7)$ & - & - & - & 7.22 , d (8.0) & $\begin{array}{l}4.11, \mathrm{~d}(15.3) \\
3.70-3.46, \mathrm{~m}\end{array}$ \\
\hline 9 & $7.10, \mathrm{~s}$ & $7.44, \mathrm{~s}$ & $7.41, \mathrm{~s}$ & $7.43, \mathrm{~s}$ & - & - \\
\hline 11 & - & - & - & - & - & $6.73-6.62, \mathrm{~m}$ \\
\hline 12 & - & - & - & - & - & 6.73-6.62, m \\
\hline 13 & - & - & - & - & - & $\begin{array}{l}\text { a) } 3.25-3.11, \mathrm{~m} \\
\text { b) } 2.92-2.74, \mathrm{~m}\end{array}$ \\
\hline 14 & _- & - & - & - & - & $3.70-3.46, \mathrm{~m}$ \\
\hline $\mathrm{NH}$ & $10.80, \mathrm{~s}$ & $10.84, \mathrm{~s}$ & $10.78, \mathrm{~s}$ & $10.65, \mathrm{~s}$ & - & - \\
\hline $\begin{array}{l}1-\mathrm{CH}_{3} \\
2-\mathrm{OCH}_{3}\end{array}$ & & & & & $2.50, \mathrm{~s}$ & $3 . \overline{87, \mathrm{~s}}$ \\
\hline $3-\mathrm{OCH}_{3}^{3}$ & - & 4.05, s & $4.03, \mathrm{~s}$ & 4.03, s & - & $3.89, \mathrm{~s}$ \\
\hline $4-\mathrm{OCH}_{3}^{3}$ & $4.02, \mathrm{~s}$ & 4.02, s & $3.99, \mathrm{~s}$ & - & - & - \\
\hline $6-\mathrm{OCH}_{3}^{3}$ & - & - & - & - & $3.91, \mathrm{~s}$ & - \\
\hline $8-\mathrm{OCH}_{3}$ & - & $4.00, \mathrm{~s}$ & - & $3.96, \mathrm{~s}$ & - & - \\
\hline $\mathrm{O}-\mathrm{CH}_{2}-\mathrm{O}$ & - & - & - & - & - & 5.95, dd $(14.6,1.6)$ \\
\hline
\end{tabular}

${ }^{\text {a }}$ Data were recorded at $400 \mathrm{MHz}$.

${ }^{\mathrm{b}}$ Data were recorded at $500 \mathrm{MHz}$.

Table S2 ${ }^{13} \mathrm{C}$ NMR data of compounds 1-6.

\begin{tabular}{|c|c|c|c|c|c|c|}
\hline position & $\begin{array}{c}1 \text { in DMSO- } d_{6} \\
\delta_{C}(\mathrm{ppm})^{\mathrm{a}}\end{array}$ & $\begin{array}{c}2 \text { in DMSO-d } \\
\delta_{C}(\mathrm{ppm})^{\mathrm{a}} \\
\end{array}$ & $\begin{array}{c}3 \text { in DMSO- } d_{6} \\
\delta_{C}(\mathrm{ppm})^{\mathrm{b}}\end{array}$ & $\begin{array}{c}4 \text { in DMSO-d }_{6} \\
\delta_{C}(\mathrm{ppm})^{\mathrm{b}}\end{array}$ & $\begin{array}{c}5 \text { in DMSO-d } \\
\delta_{C}(\mathrm{ppm})^{\mathrm{a}} \\
\end{array}$ & $\begin{array}{l}6 \text { in } \mathrm{CDCl}_{3} \\
\delta_{C}(\mathrm{ppm})^{\mathrm{a}} \\
\end{array}$ \\
\hline 1 & 122.3 & 125.2 & 121.6 & 115.9 & 147.2 & 108.5 \\
\hline 2 & 113.8 & 108.7 & 109.9 & 109.0 & 125.5 & 147.4 \\
\hline 3 & 152.7 & 154.8 & 154.2 & 148.3 & 152.6 & 147.5 \\
\hline 4 & 152.7 & 151.1 & 150.6 & 149.7 & - & 111.3 \\
\hline $4 a$ & 122.3 & 122.1 & 120.2 & 114.5 & 164.8 & 126.7 \\
\hline $4 \mathrm{~b}$ & - & - & - & - & 125.9 & - \\
\hline 5 & 126.4 & 119.7 & 118.0 & 120.1 & 143.1 & 29.1 \\
\hline $5 a$ & 127.2 & 120.4 & 127.1 & 124.1 & - & - \\
\hline 6 & 127.8 & 123.5 & 125.7 & 125.2 & 154.9 & 51.4 \\
\hline 7 & 125.8 & 110.8 & 112.1 & 107.5 & 113.1 & - \\
\hline 8 & 129.4 & 155.8 & 153.7 & 155.2 & 117.3 & 53.0 \\
\hline $8 a$ & - & - & - & - & 127.9 & 116.9 \\
\hline 9 & 104.3 & 98.4 & 98.7 & 97.9 & 191.5 & 143.3 \\
\hline $9 a$ & 135.8 & 126.2 & 124.0 & 127.5 & 126.1 & - \\
\hline 10 & 135.3 & 135.1 & 133.9 & 134.7 & - & 145.0 \\
\hline $10 \mathrm{a}$ & 120.8 & 127.2 & 123.3 & 124.1 & - & - \\
\hline 11 & - & - & - & - & - & 106.8 \\
\hline 12 & - & - & - & - & - & 121.0 \\
\hline $12 \mathrm{a}$ & - & - & - & - & - & 128.6 \\
\hline 13 & - & - & - & - & - & 36.4 \\
\hline 14 & - & - & - & - & - & 59.5 \\
\hline $14 a$ & - & - & - & - & - & 129.6 \\
\hline $\mathrm{C}=\mathrm{O}$ & 168.9 & 168.8 & 168.3 & 168.9 & - & - \\
\hline $1-\mathrm{CH}_{3}$ & - & - & - & - & 17.1 & - \\
\hline $2-\mathrm{OCH}_{3}$ & - & - & - & - & - & 55.9 \\
\hline $3-\mathrm{OCH}_{3}^{3}$ & - & 60.4 & 56.9 & 57.3 & - & 56.0 \\
\hline $4-\mathrm{OCH}_{3}^{3}$ & 59.9 & 57.4 & 59.9 & - & - & - \\
\hline $6-\mathrm{OCH}_{3}^{3}$ & - & - & - & - & 56.8 & - \\
\hline $8-\mathrm{OCH}_{3}^{3}$ & - & 56.4 & - & 55.9 & - & - \\
\hline $\mathrm{O}-\mathrm{CH}_{2}-\mathrm{O}$ & - & - & - & - & - & 101.1 \\
\hline
\end{tabular}

${ }^{\text {a }}$ Data were recorded at $100 \mathrm{MHz}$.

${ }^{\mathrm{b}}$ Data were recorded at $125 \mathrm{MHz}$. 
Table S3 HR-ESI-MS of compounds 1-6.

\begin{tabular}{llrr}
\hline \multirow{2}{*}{ Compound } & \multicolumn{3}{c}{ HRMS-ESI-TOF $(m / z$, Mol $)$} \\
\cline { 2 - 4 } & Molecular formula & Found & Calculated \\
\hline 1 & $\mathrm{C}_{16} \mathrm{H}_{12} \mathrm{NO}_{3}[\mathrm{M}+\mathrm{H}]^{+}$ & 266.0818 & 266.0817 \\
2 & $\mathrm{C}_{18} \mathrm{H}_{15} \mathrm{NO}_{4} \mathrm{Na}[\mathrm{M}+\mathrm{Na}]^{+}$ & 332.0841 & 332.0899 \\
3 & $\mathrm{C}_{17} \mathrm{H}_{14} \mathrm{NO}_{4}[\mathrm{M}+\mathrm{H}]^{+}$ & 296.1050 & 296.0923 \\
4 & $\mathrm{C}_{17} \mathrm{H}_{13} \mathrm{NO}_{4} \mathrm{Na}[\mathrm{M}+\mathrm{Na}]^{+}$ & 318.0760 & 318.0742 \\
5 & $\mathrm{C}_{14} \mathrm{H}_{11} \mathrm{NO}_{3} \mathrm{Na}[\mathrm{M}+\mathrm{Na}]^{+}$ & 264.2356 & 264.0637 \\
6 & $\mathrm{C}_{20} \mathrm{H}_{21} \mathrm{NO}_{4}[\mathrm{M}]^{+}$ & 339.1497 & 339.1471 \\
\hline
\end{tabular}

Table S4 Antimicrobial activity of compounds 2, 3, 4, and 6.

\begin{tabular}{lcccc}
\hline \multirow{2}{*}{$\begin{array}{l}\text { Sample code } \\
\text { Replicate }\end{array}$} & $\begin{array}{c}\text { Zscherichia coli } \\
\text { (ATCC25922) }\end{array}$ & $\begin{array}{c}\text { Staphylococcus aureus } \\
\text { (ATCC29213) }\end{array}$ & $\begin{array}{c}\text { Candida albicans } \\
\text { (ATCC 10231) }\end{array}$ \\
\cline { 3 - 5 } & 1 & - & - & - \\
aristolactam BI (2) & 1 & - & - & - \\
velutinam (3) & 1 & - & - & - \\
griffithinam (4) & 1 & - & 30.51 & - \\
$\begin{array}{l}\text { sinectine (6) } \\
\text { gentamicin" }\end{array}$ & & 22.54 & & 23.72 \\
penicillin" & & & & - \\
nystatin* & & & & \\
\hline
\end{tabular}

\footnotetext{
" Positive control.
} 